\title{
Hepatic expression of aminoadipate semialdehyde synthase is unchanged by postruminal lysine supply in lactating dairy cows
}

\author{
H. A. Tucker, ${ }^{*}$ M. D. Hanigan,† J. Escobar,ł P. H. Doane,§ and S. S. Donkin*1 \\ *Department of Animal Sciences, Purdue University, West Lafayette, IN 47906 \\ †Department of Dairy Science, Virginia Polytechnic Institute and State University, Blacksburg 24061 \\ $\ddagger$ Novus International Inc., St. Charles, MO 63304 \\ $\S$ Archer Daniels Midland Company, Decatur, IL 62521
}

\begin{abstract}
Lysine supply is potentially limiting for milk production in dairy cows. The availability of Lys to the mammary gland and other tissues is a function of the quantity of metabolizable Lys supplied and Lys catabolism by the liver. Likewise, Lys catabolism may be influenced by Lys supply. This study evaluated the effect of increased postruminal Lys supply on the expression of aminoadipate semialdehyde synthase ( $A A S S$, a committing step in Lys catabolism in the liver) and ornithine transcarbamoylase and argininosuccinate synthase (key urea cycle enzymes that are responsive to protein supply). Eight multiparous peak Holstein cows were used in a replicated $4 \times 4$ Latin square. Cows were fed a Lys-limiting ration and infused postruminally with $0,9,27$, or $63 \mathrm{~g} / \mathrm{d}$ of Lys. The study consisted of $10 \mathrm{~d}$ of pretreatment followed by $10 \mathrm{~d}$ of Lys infusion. On the last day of each period, liver and milk samples were collected for mRNA analysis, and blood samples were collected for analysis of amino acids and Lys metabolites. Milk protein percent increased by $5.9 \%$, plasma Lys increased by $74 \%$, and $\alpha$-aminoadipic acid increased by $51 \%$ with postruminal infusion of 63 g/d Lys compared with $0 \mathrm{~g} / \mathrm{d}$. Expression of $A A S S$, ornithine transcarbamoylase, and argininosuccinate synthase mRNA in liver did not differ with postruminal infusion of Lys. Milk fat globule mRNA for major milk proteins and $A A S S$ were not affected by Lys infusion. Postruminal infusion of Lys resulted in an $86 \%$ greater increase in $A A S S$ mRNA in the liver compared with mammary mRNA. These changes suggest that hepatic Lys metabolism is not responsive to Lys supply at the transcription level, and that the availability of Lys to extrahepatic tissue may be determined by hepatic Lys metabolism.
\end{abstract}

Received February 1, 2016.

Accepted September 27, 2016.

${ }^{1}$ Corresponding author: sdonkin@purdue.edu
Key words: lysine, gene expression, postruminal infusion

\section{INTRODUCTION}

Postruminal infusion of Lys has been used as an experimental method of providing additional absorbable lysine to dairy cows, but it has yielded inconsistent effects for milk production and composition (Rulquin et al., 1993; Robinson, 2010). The lack of predictable response to Lys infusion suggests differences in the efficiency of postruminal Lys use. A portion of this inconsistency may be due to variations in hepatic Lys catabolism, mammary Lys extraction, conversion of Lys to milk protein, or a combination of these (Lapierre and Lobley, 2001; Lobley and Lapierre, 2003).

Hepatic Lys catabolism is catalyzed by a combination of lysine ketoglutarate reductase $(L K R)$ and saccharopine dehydrogenase $(S D H)$. Both enzymes are sensitive to dietary Lys supply (Chu and Hegsted, 1976; Muramatsu et al., 1984; Blemings et al., 1990; Foster et al., 1993) and reside on the same bifunctional protein complex, aminoadipic semialdehyde synthase $(A A S S)$ (Markovitz et al., 1984; Markovitz and Chuang, 1987; Papes et al., 1999). Previous research has shown a 3 -fold increase in $L K R$ activity in rat and swine with when Lys of $2.2 \%$ of the total diet is added ( $\mathrm{Chu}$ and Hegsted, 1976; Blemings et al., 1998). Moreover, in mice, a $20 \%$ decrease in AASS mRNA abundance has been shown to correlate with a $50 \%$ reduction in the activity of $L K R$ (Cleveland et al., 2008), indicating the value of $A A S S$ mRNA as a measure of hepatic capacity for Lys catabolism. A similar change in $A A S S$ in response to postruminal Lys supply in dairy cows could reflect a portion of the observed inefficiency in milk protein response with increased postruminal Lys supply (Guinard and Rulquin, 1994).

Hepatic extraction of Lys is less than $10 \%$ of portaldrained viscera Lys flux, while mammary tissue extracts Lys in excess relative to output, resulting in an uptake to output ratio of $1.35 \pm 0.29$ (Lapierre et al., 
2003, 2005, 2012). This finding suggests limited hepatic control of Lys utilization as a potential obstacle for increasing mammary Lys supply. Furthermore, because mammary tissue utilizes an average of $86 \%$ of the mammary Lys supply for milk protein synthesis, there would appear to be little alternative metabolism of the Lys extracted by mammary tissue (Guinard and Rulquin, 1994; Lapierre et al., 2005). Determining the relative relationship for Lys utilization in liver and mammary tissue may be critical in determining whole-body AA use for protein synthesis and factors that regulate this process.

Amino acid turnover and exchange between tissues is a critical part of whole-body AA metabolism (Lapierre and Lobley, 2001). Data describing the rates and extent of Lys metabolism by liver and mammary tissue are a prerequisite for increased precision in formulating diets for lactating dairy cows based on MP requirements (Hanigan et al., 2004). There is also a need to determine physiological response to changes in Lys supply, focusing on specific changes in Lys catabolism. We hypothesize that Lys catabolism in dairy cows is responsive to postruminal Lys supply and involves changes in AASS expression in the liver. The objective of this study was to determine the effect of increasing postruminal Lys supply on mRNA transcripts of key genes in Lys and protein catabolism in liver and mammary tissue via milk fat globule. We determined the effects of Lys on AASS mRNA expression as an indicator of a gene specific to Lys catabolism and its effects on urea cycle enzymes as a general indicator of tissue response to postruminal AA supply.

\section{MATERIALS AND METHODS}

\section{Animal Use and Handling}

Eight early-lactation Holstein dairy cows, averaging $68 \pm 3$ DIM, were housed in individual tiestalls at the Purdue University Dairy Research and Education Center and used in a replicated $4 \times 4$ Latin square to evaluate the effects of postruminal Lys supply. Cows were stratified by DIM, assigned to 1 of 2 squares, and randomly assigned to a treatment sequence within the square. Each square consisted of 4 periods of 20 $\mathrm{d}$, including $10 \mathrm{~d}$ of adjustment and $10 \mathrm{~d}$ of Lys infusion. The last $4 \mathrm{~d}$ of each period were used for data collection. Animal care and handling protocols were approved by the Purdue University Animal Care and Use Committee.

All cows were fed the same corn-based ration (Table 1) delivered as a TMR once daily, and fresh water was provided freely. The corn-based ration was formulated to meet all nutrient requirements, including essential
AA except Lys, for a $560 \pm 16 \mathrm{~kg}$ cow with a BCS of $2.4 \pm 0.15$ (average for cows used during trial), supplying $\mathrm{NE}_{\mathrm{L}}$ of $32.3 \pm 0.6 \mathrm{Mcal} / \mathrm{d}$ and $\mathrm{MP}$ of $2.22 \pm 0.05$ $\mathrm{kg} / \mathrm{d}$ (NRC, 2001).

To achieve the target protein and Lys supply (5.5\% of MP), animals were limit-fed. Feed was provided based on a DMI requirement estimated by the following equation: DMI $=\left[\left(\left(\mathrm{BW}^{0.75}\right) \times 0.0968\right)+(0.372 \times \mathrm{FCM})\right.$ $-0.293] \times\left[1-\mathrm{e}^{(-1 \times 0.192 \times(\mathrm{WOL}+3.67)}\right]$, where WOL is week of lactation (NRC, 2001). Intake for each cow was adjusted weekly based on milk yield, milk composition, DIM, BCS, and BW. To avoid bias in DMI by treatment, intake was determined in a manner that was blind to treatment assignment and did not account for Lys contribution to $\mathrm{MP}$ or $\mathrm{NE}_{\mathrm{L}}$.

To assess target Lys input, we used $7.2 \%$ of MP, the model from the National Research Council (NRC, 2001). The basal diet supplied $2.24 \mathrm{~kg} / \mathrm{d}$ MP, which corresponded to $0.75 \times$ the Lys requirement (NRC, 2001). Infusion of $9 \mathrm{~g} / \mathrm{d}$ Lys increased this to $0.82 \times$ the Lys requirement. Infusion of $27 \mathrm{~g} / \mathrm{d}$ of Lys allowed for $6.7 \%$ of MP, meeting $0.93 \times$ the Lys requirement. Infusion of $63 \mathrm{~g} / \mathrm{d}$ of Lys supplied $1.15 \times$ of Lys requirements NRC (2001).

Cows were released from tiestalls and milked twice daily in a milking parlor. Milk production and feed intake were measured daily. Milk samples were collected

Table 1. Diet ingredients and nutrient composition

\begin{tabular}{lc}
\hline Item & Basal TMR \\
\hline Ingredient, \% of diet DM & \\
Corn silage & 39.5 \\
Haylage & 15.9 \\
Grass hay & 5.14 \\
Ground corn grain & 10.2 \\
Corn gluten meal & 3.21 \\
Dried distillers grains & 6.79 \\
Soybean hulls & 6.90 \\
Supplement & 12.0 \\
Nutrient, ${ }^{2} \%$ of DM & \\
CP & $15.6 \pm 0.07$ \\
RDP $^{3}$ & 10.0 \\
RUP $^{3}$ & 5.6 \\
NE & Mcal/kg \\
ADF & $1.64 \pm 0.01$ \\
NDF & $25.4 \pm 1.1$ \\
Calcium & $36.8 \pm 1.1$ \\
Phosphorus & $1.06 \pm 0.02$ \\
\hline
\end{tabular}

${ }^{1}$ Contains: $37.0 \%$ ground corn, $24.3 \%$ dried molasses, $7.29 \%$ calcium carbonate, $7.25 \%$ Enertia (ADM, Quincy, IL), $5.52 \%$ sodium bicarbonate, $4.92 \%$ urea, $3.31 \%$ salt, $2.87 \%$ monocalcium phosphate, $1.68 \%$ XP yeast (Diamond V, Cedar Rapids, IA), 1.61\% Smartamine M (Adisseo, Alpharetta, GA), 1.59\% Omnigen (Phibro Animal Health Corporation, Teaneck, NJ) $1.55 \%$ magnesium oxide, $0.94 \%$ trace mineral and vitamin pack, $0.16 \%$ vitamin E premix, and $0.05 \%$ Rumensin 80 (Elanco, Greenfield, IN).

${ }^{2}$ Values are presented as average of 4 samples \pm SE.

${ }^{3}$ Calculated using NRC (2001) ration evaluator. 
during the last 8 consecutive milkings of each period and analyzed for fat, protein, lactose, total solids, MUN, and somatic cells by Dairy One (Ithaca, NY). Milk Lys content was calculated using the constant of $86.5 \mathrm{mg}$ of Lys/g of milk protein (Davis et al., 1994; Marino et al., 2010). We used the ratio of calculated milk Lys content to Lys infused as a measure of Lys efficiency. Dry matter intake was determined by difference from feed offered and refused when refusals were present; however, because cows were fed to target DMI, refusals were not generally observed. Samples of TMR were collected during the last $4 \mathrm{~d}$ of each period, dried in a forced-air oven at $60^{\circ} \mathrm{C}$, and ground to pass a $2-\mathrm{mm}$ screen. A composite sample of the diet was formed for the experiment and analyzed for DM, CP, ADF, and minerals by a commercial lab (Dairy One) using wet chemistry and following AOAC methods (AOAC International, 2000) and for NDF (Goering and Van Soest, 1970; Van Soest et al., 1991).

\section{Infusion Procedure}

On d 10 of each period, cows were fitted with infusion lines that extended through the rumen cannula to the abomasum following the procedure of Gressley et al. (2006). Lines were checked daily for patency of placement through the reticulo-omasal orifice. Infusions consisting of $0,9,27$, or $63 \mathrm{~g}$ of L-Lys (ADM Liquid Llysine 50\%; Archer Daniels Midland, Decatur, IL) were administered continuously over 22.5 -h. This permitted approximately $1.5 \mathrm{~h} / \mathrm{d}$ for cows to be moved to a milking parlor for milking. The infusate was prepared fresh each day by dilution in water at 30 to $39^{\circ} \mathrm{C}$ so that the total volume of infusate was $4 \mathrm{~L} / \mathrm{d}$, regardless of total quantity of Lys infused.

\section{Measurement of Blood Metabolites}

Blood samples were collected on the last day of each period by puncture of a coccygeal vessel into Vacutainers containing sodium heparin (BD Diagnostics, Franklin Lakes, NJ). Plasma was separated by centrifugation at $2,000 \times g$ for $15 \mathrm{~min}$ at $4^{\circ} \mathrm{C}$ and analyzed for urea nitrogen (Urea Nitrogen Test, reference no. 0580-250; Stanbio Laboratory Inc., Boerne, TX), glucose (Glucose Test C, reference no. 439-90901; Wako Chemicals USA Inc., Richmond, VA), BHB (procedure no. 2440; Stanbio Laboratory Inc.), and fatty acids (HR Series NEFA-HR 1, reference no. 999-34691, 9991-34891, 993-35191; Wako Chemicals USA Inc.). An aliquot $(5 \mathrm{~mL})$ of plasma was shipped on dry ice to Virginia Tech University (Blacksburg) and analyzed for AA and $\alpha$-aminoadipic acid following the methods of Burrin et al. (1995).

\section{Liver mRNA Sample Handling and Analysis}

On the final day of each period, liver tissue was collected by blind percutaneous needle biopsy (Greenfield et al., 2000). Approximately $100 \mathrm{mg}$ of liver was rinsed in saline, transferred to a fresh tube containing QIAzol lysis reagent (Qiagen, Thousand Oaks, CA), and frozen in liquid nitrogen and stored at $-80^{\circ} \mathrm{C}$ until RNA extraction and analysis. Samples were homogenized in QIAzol lysis reagent (Qiagen) using an Ultra Turrax fitted with a S25M-8G dispersing tool (IKA Labortechnix, Wilmington, NC), and RNA was extracted according to the manufacturer's directions (https://www. qiagen.com/us/). Resulting total RNA was quantified by absorbance at $260 \mathrm{~nm}$ using a ND-1000 spectrophotometer (NanoDrop Technologies Inc., Wilmington, DE). The quality of the RNA was determined using the ratio of absorbance at $260 \mathrm{~nm}$ to that at $280 \mathrm{~nm}$, and the RNA integrity number was obtained using the Agilent Technologies Bioanalyzer System (Santa Clara, CA). Only RNA samples with a 260:280 ratio between 1.8 and 2.2 and RNA integrity number scores $>7.0$ were used for subsequent analysis. A 100- $\mu$ g aliquot of each RNA sample was treated with DNase I and further purified using the RNeasy Mini Kit (Qiagen Inc.). A 2- $\mu \mathrm{g}$ aliquot of the resulting RNA was reverse-transcribed using an Omniscript reverse transcriptase kit (Qiagen Inc.), oligo-dT (0.05 $\mu \mathrm{g} / \mu \mathrm{L}$; Qiagen Inc.), and random decamers $(10 \mu M$; Ambion, Foster City, CA).

\section{Milk Fat Globule mRNA Sample Handling and Analysis}

Milk samples were collected from the morning milking on the final day of each period and subjected to RNA analysis using the methods of Brenaut et al. (2012) and Cánovas et al. (2014) with the following modifications. Milk samples $(45 \mathrm{~mL})$ were collected into RNase-free sample bottles, transferred into sterile $50 \mathrm{~mL}$ conical tubes, and stored on ice. Samples were centrifuged at 2,000 $\times g$ for 10 min (Beckman J-6B; Beckman Coulter, Inc., Indianapolis, IN) to separate fat from other milk components. The resultant fat was suspended in RNase-free water (1:1), and an equal volume of TRIzol LS (Life Technologies, Grand Island, NY) was added and thoroughly mixed. All samples were stored at $-80^{\circ} \mathrm{C}$ until analysis. Chloroform was added to thawed samples, they were centrifuged at $12,000 \times$ $g$, and the resultant aqueous phase was combined with an equal volume of acid phenol:chloroform-isoamyl alcohol (Ambion, Life Science Technologies). Samples were centrifuged at $12,000 \times g$, and the aqueous phase was combined with an equal volume of $70 \%$ ethanol, vortexed, and purified using the RNeasy Mini Kit and 
treated with DNase I (Qiagen Inc.). The resulting total RNA was quantified by absorbance at $260 \mathrm{~nm}$ using a ND-1000 spectrophotometer (NanoDrop Technologies Inc.), and RNA quality was assessed as per liver RNA, with the notable exception that RNA integrity number scores were not used as a quality assessment. The substantial fraction of low-molecular-weight RNA inherent in samples of RNA isolated from milk fat negatively affects RNA integrity number, but does not appear to affect the utility of this RNA source in studying of mammary gene expression (Cánovas et al., 2014). A 2- $\mu \mathrm{g}$ aliquot of the resulting RNA was reversetranscribed using an Omniscript reverse transcriptase kit (Qiagen Inc.), oligo-dT (0.05 $\mu \mathrm{g} / \mu \mathrm{L}$; Qiagen Inc.), and random decamers (10 $\mu M$; Ambion).

\section{Quantitative Real-Time PCR}

We determined the abundance of $O T C$ (EC 2.1.3.3), $A S S-1$ (EC 6.3.4.5), AASS (EC 1.5.1.8 and EC 1.5.1.9), and $18 S$ (gene ID 493779) mRNA in liver RNA samples and the abundance of $\beta$-casein (gene ID 1039919), $\kappa$-casein (gene ID 28589), $\alpha$-LA ( $L A L B A$, gene ID 62509), AASS (EC 1.5.1.8 and EC 1.5.1.9), and $18 S$ (gene ID 493779) mRNA in mammary RNA samples using quantitative real-time PCR. Reactions contained brilliant SYBR Green reagent, QPCR master mix (Stratagene, Cedar Creek, TX), and the primers indicated in Table 2. An equal amount of purified RNA from each sample was combined; an aliquot was used as an assay control for the no-reverse-transcriptase reaction and water served as the control for the no-PCR template control. A cDNA pool was formed from equal quantities of cDNA from each sample and used to generate a standard curve for each real-time PCR assay. All PCR reactions were as follows: 1 cycle at $95^{\circ} \mathrm{C}$ for 3 min; 40 cycles of $95^{\circ} \mathrm{C}$ for $10 \mathrm{~s}$ and $60^{\circ} \mathrm{C}$ for $20 \mathrm{~s}$; and 1 cycle of $95^{\circ} \mathrm{C}$ for $1 \mathrm{~min}, 55^{\circ} \mathrm{C}$ for $30 \mathrm{~s}$, and $95^{\circ} \mathrm{C}$ for $30 \mathrm{~s}$. Reaction efficiencies were between 90 and $110 \%$ based on analysis of each standard curve. Samples, standards, and controls were analyzed in triplicate. Mean values for each transcript were determined relative to a standard curve. Abundance of each transcript is expressed in arbitrary units relative to $18 S \mathrm{mRNA}$ abundance. Use of $18 S$ for data normalization was verified not to have bias by the lack of an effect of treatment on threshold cycle or quantity.

\section{Statistical Analysis}

Data were analyzed using the MIXED procedure in SAS 9.2 with repeated measures (SAS Institute Inc., Cary, NC). The normality of data was determined using the UNIVARIATE procedure in SAS 9.2 and the

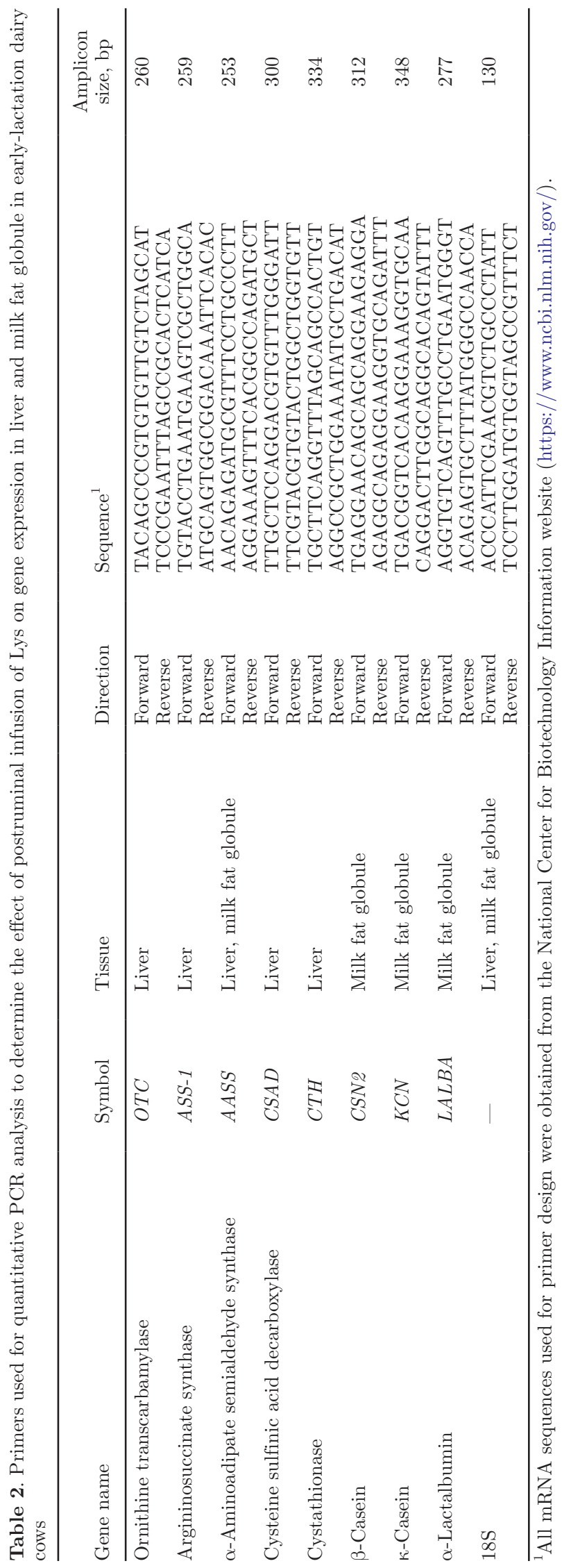


Table 3. Effect of postruminal Lys infusion on performance of early-lactation dairy cows

\begin{tabular}{|c|c|c|c|c|c|c|c|c|c|}
\hline Item & \multicolumn{4}{|c|}{ Lys infusion, ${ }^{1} \mathrm{~g} / \mathrm{d}$} & $\mathrm{SE}$ & \multicolumn{4}{|c|}{$P$-value } \\
\hline DMI, kg & $20.4^{\mathrm{a}}$ & $21.4^{\mathrm{b}}$ & $20.2^{\mathrm{a}}$ & $20.4^{\mathrm{a}}$ & 0.5 & $<0.05$ & 0.12 & $<0.05$ & $<0.05$ \\
\hline \multicolumn{10}{|c|}{ Milk component yield, $\mathrm{g} / \mathrm{d}$} \\
\hline Fat & 948 & 1,003 & 955 & 1,001 & 57 & 0.46 & 0.42 & 0.89 & 0.17 \\
\hline Protein & 773 & 805 & 829 & 805 & 28 & 0.14 & 0.11 & 0.10 & 0.60 \\
\hline \multicolumn{10}{|c|}{ Milk component, $\%$ of milk } \\
\hline Fat & 3.10 & 3.29 & 3.12 & 3.30 & 0.13 & 0.27 & 0.29 & 0.93 & 0.10 \\
\hline Protein & $2.53^{\mathrm{a}}$ & $2.66^{\mathrm{ab}}$ & $2.72^{\mathrm{b}}$ & $2.68^{\mathrm{b}}$ & 0.05 & $<0.05$ & $<0.05$ & $<0.05$ & 0.84 \\
\hline Lactose & 4.79 & 4.89 & 4.81 & 4.81 & 0.05 & 0.40 & 0.95 & 0.29 & 0.18 \\
\hline Total solids & 11.3 & 11.7 & 11.5 & 11.6 & 0.21 & 0.21 & 0.15 & 0.27 & 0.25 \\
\hline MUN, mg/dL & 8.2 & 9.0 & 8.8 & 10.1 & 0.63 & 0.19 & 0.05 & 0.72 & 0.38 \\
\hline Milk Lys, ${ }^{2} \mathrm{~g} / \mathrm{d}$ & 67.0 & 69.9 & 71.7 & 69.3 & 2.5 & 0.25 & 0.24 & 0.11 & 0.66 \\
\hline
\end{tabular}

${ }^{\mathrm{a}, \mathrm{b}}$ Means within a row with different superscripts differ $(P<0.05)$.

${ }^{1}$ Data are presented as means of 8 animals per treatment.

${ }^{2}$ Calculated milk Lys content using a constant of $86.5 \mathrm{mg}$ of Lys/g of protein (Davis et al., 1994; Marino et al., 2010).

${ }^{3}$ Lysine efficiency is the quotient of the increase in calculated milk Lys content from infusion on $0 \mathrm{~g} / \mathrm{d}$ Lys and the concentration of Lys postruminally infused.

Shapiro-Wilk test. Heteroscedasticity was corrected by a square-root transformation. Transformed data that met the test for normality were further analyzed using the MIXED procedure in SAS 9.2. The model for milk production, DMI, milk composition, blood AA and metabolites, and gene expression accounted for the effects of Lys level, square, period, and the random effect of cow nested within square. Means were considered different when $P<0.05$ and tended to differ if $0.05 \leq P \leq$ 0.10 . Tukey-Kramer studentized adjustments were used for multiple comparisons. Data are reported as least squares means with associated standard errors, except transformed data (liver and milk fat globule gene expression), which were back-transformed to physiologically meaningful values and reported with a $95 \%$ confidence interval. Preplanned orthogonal contrasts of $0 \mathrm{~g} / \mathrm{d}$ Lys versus 9,27 , and $63 \mathrm{~g} / \mathrm{d}$ Lys were used to evaluate the effect of Lys infusion on DMI. Linear, quadratic, and cubic contrasts were conducted to evaluate response to Lys infusion of all measures.

\section{RESULTS}

\section{DMI and Milk Production}

Analysis of $0 \mathrm{~g} / \mathrm{d}$ Lys versus the combined effects of 9, 27, and $63 \mathrm{~g} / \mathrm{d}$ indicated that infusion of Lys did not significantly alter DMI (20.4 vs. $20.7 \pm 0.5 \mathrm{~kg} / \mathrm{d}$; Table $3)$. We observed a tendency $(P<0.1)$ for a significant interaction of period and treatment for DMI. Infusion of Lys altered $(P<0.05)$ milk yield ( 0 vs. all others).
We observed a cubic effect of Lys to increase $(P<0.05)$ milk yield.

\section{Milk Composition}

Postruminal infusion of Lys did not alter milk protein yield $(\mathrm{g} / \mathrm{d}$; Table 3 ). Postruminal infusion of Lys linearly increased $(P<0.05)$ milk protein percent, where infusion of 27 or $63 \mathrm{~g} / \mathrm{d}$ of Lys results were elevated above the control $(2.72$ or 2.68 vs. $2.53, P<0.05$ ). Lysine infusion did not alter total milk fat, lactose, and total solids yield or percent in milk. Postruminal infusion of Lys did not alter MUN, although it was numerically greater for cows receiving $63 \mathrm{~g} / \mathrm{d}$ of Lys. We observed a linear effect $(P<0.05)$ of Lys infusion to increase MUN. Postruminal infusion of Lys did not alter milk Lys concentrations.

\section{Blood Metabolites}

Postruminal infusion of Lys resulted in greater $(P$ $<0.05)$ plasma Lys, being greatest with infusion of 27 and $63 \mathrm{~g} / \mathrm{d}$ Lys (Figure 1). We observed a linear effect $(P<0.05)$ of Lys infusion to increase plasma Lys (39.5, $45.8,60.7$, and $68.7 \mu M$, respectively). Postruminal infusion of $63 \mathrm{~g} / \mathrm{d}$ of Lys increased $(P<0.05)$ plasma $\alpha$-aminoadipic acid, a product of Lys catabolism, compared with all other Lys infusion levels (Figure 1). We observed a linear effect $(P<0.05)$ of Lys infusion to increase plasma $\alpha$-aminoadipic acid $(3.11,2.81,2.94$, and $4.69 \mu M$ respectively). 
Table 4. Effect of postruminal Lys infusion on AA and metabolite concentrations in plasma from lactating dairy cows

\begin{tabular}{|c|c|c|c|c|c|c|c|c|}
\hline Item & \multicolumn{4}{|c|}{ Lys infusion, ${ }^{1} \mathrm{~g} / \mathrm{d}$} & $\mathrm{SE}$ & \multicolumn{3}{|c|}{$P$-value } \\
\hline \multicolumn{9}{|l|}{$\mathrm{AA}, \mu M$} \\
\hline $\operatorname{Arg}$ & $47.1^{\mathrm{xy}}$ & $44.1^{\mathrm{x}}$ & $55.5^{\mathrm{y}}$ & $53.2^{\mathrm{xy}}$ & 3.7 & 0.08 & 0.05 & 0.07 \\
\hline His & $24.4^{\mathrm{a}}$ & $16.5^{\mathrm{b}}$ & $18.4^{\mathrm{ab}}$ & $14.2^{\mathrm{b}}$ & 1.9 & $<0.05$ & $<0.05$ & 0.06 \\
\hline Leu & $177^{\mathrm{ab}}$ & $155^{\mathrm{a}}$ & $191^{\mathrm{b}}$ & $176^{\mathrm{ab}}$ & 7.9 & $<0.05$ & 0.38 & $<0.05$ \\
\hline \multicolumn{9}{|l|}{ Metabolites } \\
\hline $\mathrm{BHB}, \mathrm{mmol} / \mathrm{L}$ & 0.43 & 0.45 & 0.47 & 0.41 & 0.03 & 0.29 & 0.82 & 0.55 \\
\hline Glucose, $\mathrm{mg} / \mathrm{dL}$ & 60.8 & 64.2 & 62.2 & 63.7 & 1.52 & 0.34 & 0.29 & 0.17 \\
\hline Fatty acids, mmol/L & 0.39 & 0.37 & 0.38 & 0.38 & 0.04 & 0.99 & 0.90 & 0.94 \\
\hline Urea nitrogen, $\mathrm{mg} / \mathrm{dL}$ & 11.0 & 10.8 & 11.4 & 10.8 & 0.40 & 0.13 & 0.94 & $<0.05$ \\
\hline
\end{tabular}

\footnotetext{
${ }^{\mathrm{a}, \mathrm{b}}$ Means within a row with different superscripts differ $(P<0.05)$.

${ }^{\mathrm{x}, \mathrm{y}}$ Means within a row with different superscripts tend to differ $(P<0.1)$.

${ }^{1}$ Data are presented as means of 8 animals per treatment.
}

Postruminal infusion of Lys tended to reduce $(P=$ $0.06)$ plasma Ala (Table 4$)$. We observed a linear $(P<$ $0.05)$ and cubic $(P<0.05)$ effect of infusion on plasma Arg; lowest levels were observed with infusion of $9 \mathrm{~g} / \mathrm{d}$ Lys. Lysine infusion reduced $(P<0.05)$ plasma His and Leu. We observed a cubic effect $(P<0.05)$ of infusion on plasma Leu. We observed a cubic effect $(P<0.05)$
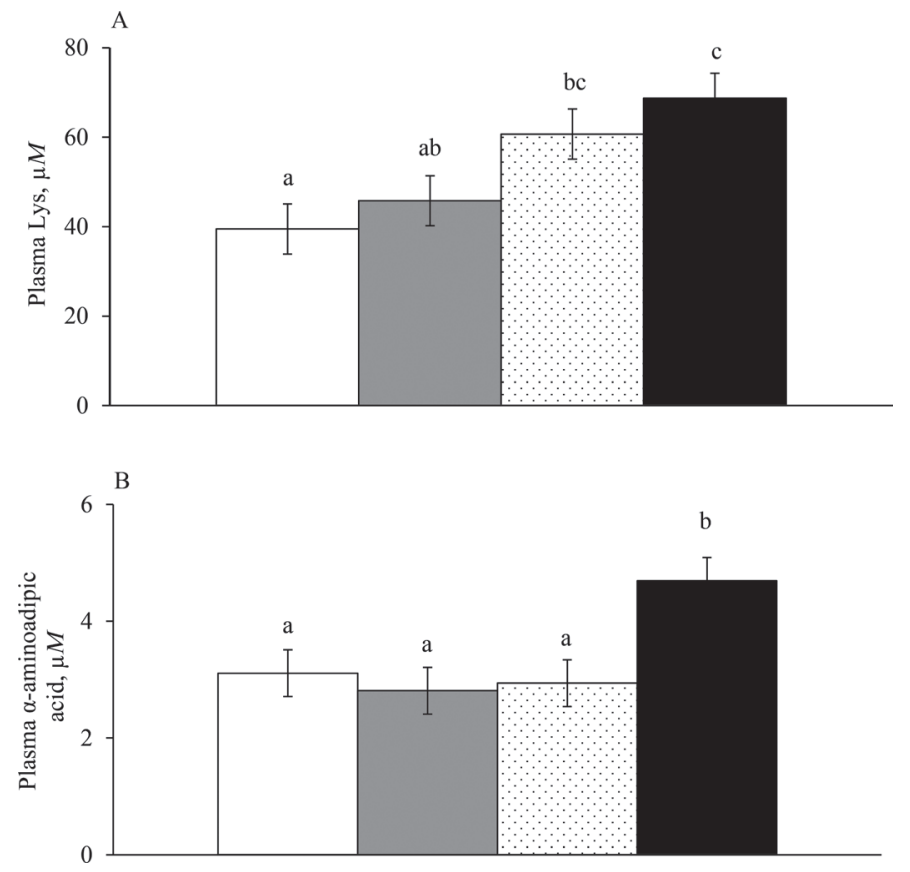

Figure 1. Effect of postruminal Lys infusion on (A) Lys and (B) $\alpha$-aminoadipic acid concentrations in plasma. Postruminal Lys infusion was provided at 4 infusion levels: $0 \mathrm{~g} / \mathrm{d}$ (white), $9 \mathrm{~g} / \mathrm{d}$ (gray), 27 $\mathrm{g} / \mathrm{d}$ (dotted), and $63 \mathrm{~g} / \mathrm{d}$ (black). Data are presented as means of 8 animals per treatment and SE. Means with different letters $(\mathrm{a}, \mathrm{b}, \mathrm{c})$ differ $(P<0.05)$. of Lys infusion on plasma Met and an overall tendency $(P=0.09)$ for Lys infusion to reduce plasma Met. Lysine infusion did not alter plasma Orn. Postruminal infusion of Lys altered $(P<0.05)$ plasma Ser in a cubic response; lowest levels were observed with infusion of $9 \mathrm{~g} / \mathrm{d}$ Lys. Postruminal infusion of lysine did not alter plasma urea nitrogen, glucose, BHB, and fatty acid concentrations.

\section{Liver and Mammary mRNA}

Postruminal infusion of Lys did not result in significant changes in abundance of hepatic OTC mRNA, although abundance was numerically greater for $27 \mathrm{~g} / \mathrm{d}$ and $63 \mathrm{~g} / \mathrm{d}$ compared to $0 \mathrm{~g} / \mathrm{d}$ (Figure 2). Lysine infusion did not alter abundance of hepatic $A S S-1$ mRNA. Postruminal infusion of Lys did not result in significant changes in the abundance of hepatic $A A S S$ mRNA, although abundance was numerically greater for 63 $\mathrm{g} / \mathrm{d}$ compared to $0 \mathrm{~g} / \mathrm{d}$. Abomasal infusion of Lys did not alter the abundance of $\beta$-casein mRNA, $\kappa$-casein mRNA, LALBA mRNA, or AASS mRNA in mammary samples (Table 5). We observed no significant linear, quadratic, or cubic effects of infusion on any of the measures of liver and mammary mRNA abundance. Postruminal infusion of $63 \mathrm{~g} / \mathrm{d}$ of Lys increased $(P<$ $0.05)$ expression of $A A S S$ mRNA in liver relative to mammary compared to any level of Lys infusion (Figure $3 ; 1.62,0.85,1.20$, and 3.02 for $0,9,27$, and $63 \mathrm{~g} / \mathrm{d}$ Lys).

\section{DISCUSSION}

The target Lys supply to cows in this study was $7.2 \%$ of MP, which is $100 \%$ of the recommended value (NRC, 


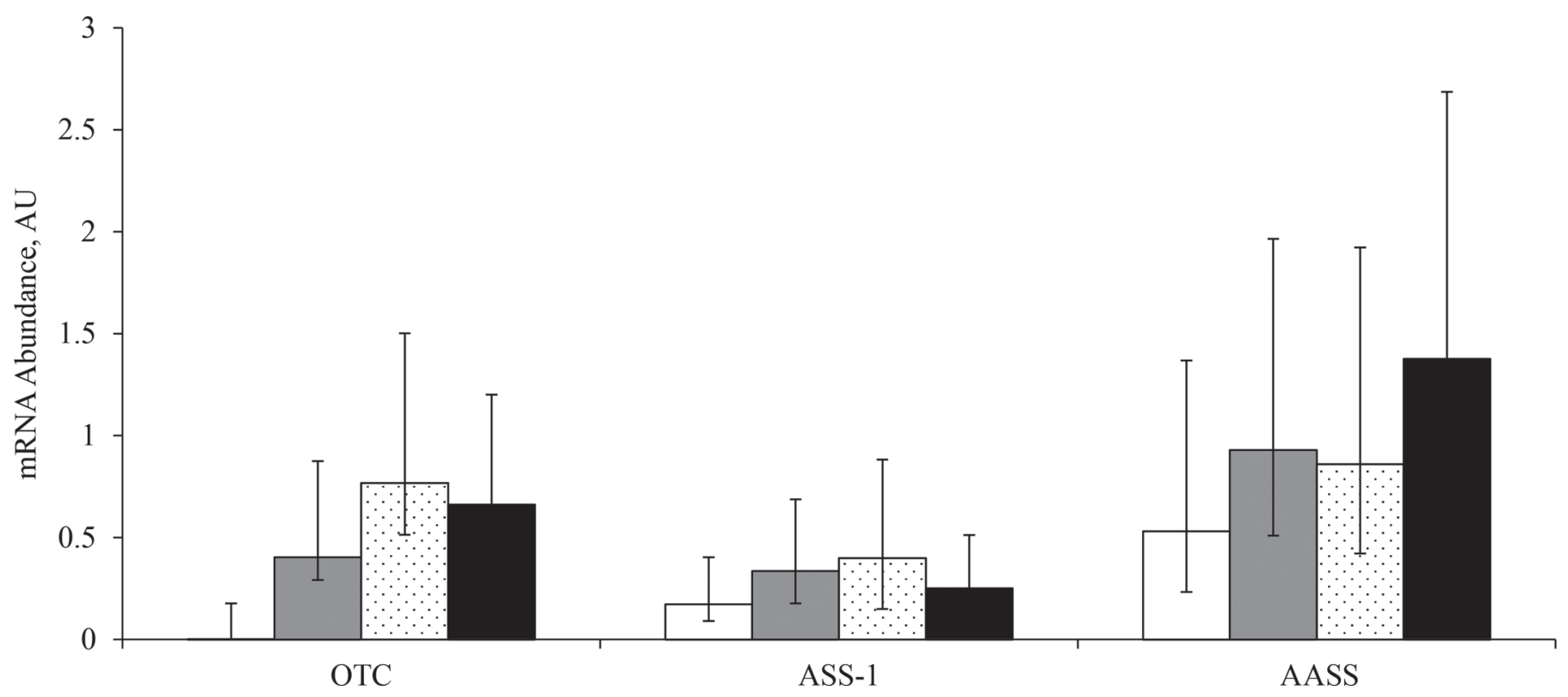

Figure 2. Expression of protein and Lys catabolism genes in liver tissue of cows provided additional Lys via postruminal infusion. Postruminal Lys infusion was provided at 4 levels: $0 \mathrm{~g} / \mathrm{d}$ (white), $9 \mathrm{~g} / \mathrm{d}$ (gray), $27 \mathrm{~g} / \mathrm{d}$ (dotted), and $63 \mathrm{~g} / \mathrm{d}$ (black). Data are presented as back-transformed LSM from 8 animals per treatment and corresponding 95\% CI, due to non-normality of data distribution. Genes: OTC $=$ ornithine transcarbamoylase; $A S S-1=$ argininosuccinate synthase; $A A S S=$ aminoadipate semialdehyde synthase. $\mathrm{AU}=$ arbitrary units.

2001). Using actual animal inputs from cows on study, the calculated MP of the basal ration (no infused Lys) supplied $75 \%$ of the identified Lys needed, or $5.4 \%$ of the MP (NRC, 2001). Infusion of 9 and $27 \mathrm{~g} / \mathrm{d}$ Lys increased total postruminal Lys to 82 or $93 \%$ of recommended levels, 5.9 and $6.7 \%$ of MP, respectively. Infusion of $27 \mathrm{~g} / \mathrm{d}$ of Lys was a close approximation of the practical recommendations of $6.6 \%$ of MP supplied as Lys when high-producing cows are fed corn-based diets established by Schwab and Ordway (2004). Infusion of $63 \mathrm{~g} / \mathrm{d}$ of Lys supplied $115 \%$ of recommended levels, or

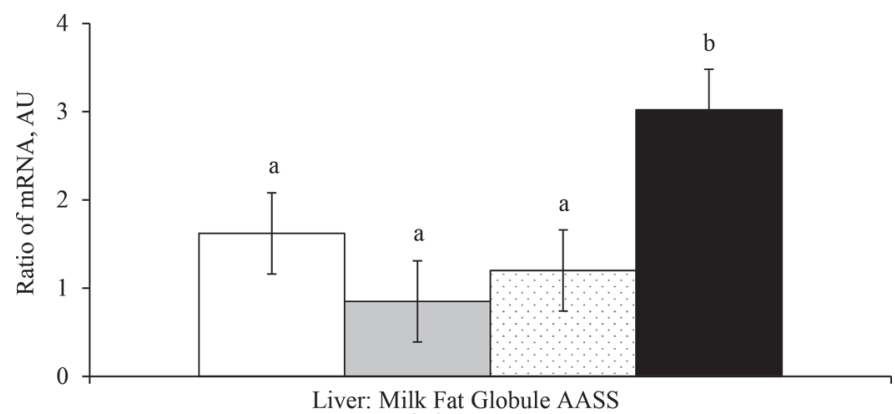

Figure 3. Expression of aminoadipate semialdehyde synthase $(A A S S)$ in liver tissue relative to its expression in milk fat globule in early-lactation dairy cows. Postruminal Lys infusion was provided at 4 different levels: $0 \mathrm{~g} / \mathrm{d}$ (white), $9 \mathrm{~g} / \mathrm{d}$ (gray), $27 \mathrm{~g} / \mathrm{d}$ (dotted), and $63 \mathrm{~g} / \mathrm{d}$ (black). AU $=$ arbitrary units. Data are presented as means of 8 animals per treatment. Means with different letters $(\mathrm{a}, \mathrm{b})$ differ $(P<0.05)$.
$8.3 \%$ of MP (NRC, 2001). In addition, the calculated energy balance for all cows was positive for the duration of the study, suggesting that the effects of Lys infusion are due to changes in Lys profile rather than energy status.

Increases in plasma Lys concentrations of $74 \%$ with $63 \mathrm{~g} / \mathrm{d}$ Lys infusion agree with previous reports (King et al., 1991; Guinard and Rulquin, 1994; Varvikko et al., 1999; Lapierre et al., 2009) evaluating the effects of Lys supply on circulating AA. Plasma concentrations of AA are used as an indicator of AA sufficiency due to hepatic maintenance of plasma AA concentrations within physiological limits while supplying AA to support peripheral tissue anabolism (Lobley and Lapierre, 2003). However, variation in plasma AA concentrations due to differing synthesis and extraction rates from circulation makes it difficult to use plasma AA concentrations as an indicator of AA sufficiency (Guinard and Rulquin, 1994). A previous study with postruminal infusion of 27 and $63 \mathrm{~g} / \mathrm{d}$ Lys in cows with lower DMI $(16.8 \pm 0.4 \mathrm{~kg} / \mathrm{d})$ and milk production $(22.0$ $\pm 0.9 \mathrm{~kg} / \mathrm{d}$ ) observed a plateau effect in plasma Lys concentrations (Guinard and Rulquin, 1994). Failure to observe a similar response in the present study suggests increased use of Lys supply relative to demand with higher milk production, as well as suggesting that infusion of $63 \mathrm{~g} / \mathrm{d}$ of Lys was greater than needed. An alternative may be that Lys use is limited, resulting in greater accumulation of Lys in plasma. Moreover, 
Table 5. Expression of milk protein and Lys catabolism genes in milk fat globule of cows given additional Lys via postruminal infusion

\begin{tabular}{|c|c|c|c|c|c|c|}
\hline mRNA & \multicolumn{4}{|c|}{ Lys infusion, ${ }^{1} \mathrm{~g} / \mathrm{d}$} & CI & $P$-value \\
\hline$\beta-\mathrm{CN}$ & 1.74 & 0.75 & 1.24 & 1.48 & $(0.70,1.51)$ & 0.14 \\
\hline$\alpha-L A$ & 1.22 & 0.67 & 1.28 & 1.21 & $(0.66,1.28)$ & 0.59 \\
\hline$\alpha$-Aminoadipate semialdehyde synthase & 0.62 & 0.92 & 0.79 & 0.60 & $(0.47,0.84)$ & 0.64 \\
\hline
\end{tabular}

${ }^{1}$ Data are presented as back-transformed LSM of 8 animals per treatment and corresponding 95\% CI, due to non-normality of data distribution.

increases in plasma Lys concentrations of cows in the present study were proportional to increased Lys supply, resulting in a significant linear regression. Together, these suggest that other factors may control Lys use, such as intestinal Lys catabolism (Gatrell et al., 2013), mammary synthesis of essential AA from Lys (Lapierre et al., 2009), or other unidentified processes.

Tissue-specific responses to Lys supply have been shown to alter $A A S S$ activity and abundance in several species (Cleveland et al., 2008; Pink et al, 2011). The lack of response of $A A S S$ abundance to postruminal infusion of Lys when matched with increasing plasma $\alpha$-aminoadipic acid in the present study suggests alternative metabolism of Lys or adequate basal Lys catabolism that lacks induction when Lys is supplied up to requirement in lactating dairy cows. In vitro analyses have indicated inhibition of $L K R$ activity by $30 \%$ in the presence of $0.2 \mathrm{~m} M \alpha$-aminoadipic acid in porcine liver mitochondria (Pink et al., 2011) although $0.2 \mathrm{~m} M \alpha$-aminoadipic may not be a physiologically relevant concentration. Additionally, a 50\% reduction in $L K R$ activity in murine cell lines correlated to a $20 \%$ decrease in $A A S S$ mRNA abundance (Cleveland et al., 2008). The observed increase in $\alpha$-aminoadipic acid and lack of change in $A A S S$ mRNA abundance suggests a disconnect between AASS mRNA abundance and enzymatic activity in bovine liver. This disconnect may arise because Lys catabolism is primarily under allosteric control by $\alpha$-aminoadipic acid activation of $A A S S$, as suggested elsewhere (Pink et al., 2011). However, without measuring $A A S S$ protein abundance or activity in the present study, the exact link between $\alpha$-aminoadipic acid and $A A S S$ mRNA is unclear. Because Lys is a potentially limiting AA for milk and milk protein synthesis, the role of $\alpha$-aminoadipic acid in regulating Lys catabolism via $A A S S$ warrants further investigation in bovine liver to determine tissue-specific indicators of Lys status.

The abundance of $O T C$ and $A S S-1$ mRNA did not change with postruminal infusion of Lys. The inability to alter $O T C$ and $A S S-1$ in rat liver with increased Lys supply has been observed previously (Snodgrass and Lin, 1981). Lack of response of $O T C$ or $A S S-1$ abundance to postruminal infusion of Lys suggests that hepatic ureagenesis is not responsive to additional nitrogen provided by increasing Lys supply in bovine from 9 to $63 \mathrm{~g}$ Lys/d, suggesting that the reserve capacity of ureagenesis is able to accommodate the increased nitrogen load.

The NRC recommends Lys be supplied at $7.2 \%$ of MP for maximal milk protein yield (NRC, 2001), while others have suggested optimal inclusion at $6.6 \%$ of MP (Schwab and Ordway, 2004). Gains in milk protein content are minimal when Lys supply is increased from 6.6 to $7.2 \%$ of MP and there is a net effect of increasing Lys transfer (Schwab and Ordway, 2004). The linear increase in milk protein percent in the present study with postruminal infusion of Lys $27 \mathrm{~g} / \mathrm{d}$ with $6.7 \%$ of MP supplied as Lys supports observations of Schwab and Ordway (2004). Inability to increase milk protein yield with greater Lys supply suggests limitations in Lys transfer to milk protein in mammary tissue (Guinard and Rulquin, 1994) or that protein synthesis in mammary tissue is already at its maximum rate for Lys use. Mammary tissue extraction of Lys results in an uptake to output ratio of $1.35 \pm 0.29$ (Lapierre et al., 2003, 2005, 2012). Additionally, mammary tissue uses, on average, $86 \%$ of mammary Lys supply for milk protein synthesis, suggesting little alternative metabolism of the Lys extracted (Guinard and Rulquin, 1994; Lapierre et al., 2005).

Assessing transcriptional activity of secretory mammary epithelium may suggest altered protein synthesis in response to increased Lys supply. Mammary biopsy has been used to characterize transcriptional activity in mammary cells in response to an altered nutritional plane. However, recent research (Cánovas et al., 2014) compared 5 different sources of mammary RNA to define the bovine mammary gland transcriptome. A high correlation $(\mathrm{r}=0.90)$ between gene expression levels in mammary gland tissue and that of milk fat globule was observed, indicating that milk fat globule mRNA could be an alternative to RNA derived from mammary gland biopsy (Cánovas et al., 2014). Gene expression analysis using milk fat globule in the present study showed a lack of response in milk protein mRNA with postruminal Lys infusion. This suggests an insensitivity of mammary tissue to Lys when supplied as a single AA and 
that Lys was in adequate supply at the transcription level. These conclusions are supported by the observed increase in plasma Lys. Additionally, calculated milk Lys content did not differ, further supporting insensitivity of mammary tissue to Lys supply.

As an indicator of relative response of mammary and liver to Lys supply, we determined the impact of Lys infusion on the ratio of $A A S S$ in liver to $A A S S$ in milk fat globule mRNA samples. Postruminal infusion of 63 $\mathrm{g} / \mathrm{d}$ of Lys resulted in an $86 \%$ increase in the ratio of $A A S S$ in liver to $A A S S$ in milk fat globule, although when each tissue was considered individually, we observed no change in $A A S S$. Priority in tissue-specific Lys use may result in inefficiencies in whole-body Lys use (Lapierre and Lobley, 2001). The modest response in milk protein synthesis to altered AA supply suggests that other tissues, including liver, may coordinate nutrient use to marginalize or complement mammary tissue needs (Berthiaume et al., 2001; Cant et al., 2002), or that liver is catabolizing nutrient that mammary is not using (Hanigan et al., 1998). The increased ratio of $A A S S$ mRNA abundance in liver to mammary tissue with modest increases in milk protein yield would support a hierarchy of Lys metabolism between tissues. Determining connections between associated tissues and how the observed hierarchy of Lys use alters the response to Lys supply provides needed data on wholebody Lys use in lactating dairy cows.

\section{CONCLUSIONS}

Postruminal Lys infusion resulted in increased plasma Lys and $\alpha$-aminoadipic acid. The mRNA for $A A S S$ (a key Lys catabolic gene) and OTC and ASS-1 (key ureagenic genes) were not responsive to postruminal Lys infusion in early-lactation dairy cows. Milk protein synthesis mRNA and AASS mRNA abundance in mammary samples were not altered by Lys supply. Postruminal infusion of Lys resulted in a greater increase in $A A S S$ expression in liver than in mammary samples. These data suggest a hierarchy in tissue use of Lys in addition to indicators of increased Lys catabolism.

\section{ACKNOWLEDGMENTS}

This work was supported by the Archer Daniels Midland Company and the Indiana Agricultural Research Station as part of NC-2040.

\section{REFERENCES}

AOAC International. 2000. Official Methods of Analysis. 17th ed. AOAC International, Arlington, VA.

Berthiaume, R., P. Dubreuil, M. Stevenson, B. W. McBride, and H. Lapierre. 2001. Intestinal disappearance and mesenteric and portal appearance of amino acids in dairy cows fed ruminally protected methionine. J. Dairy Sci. 84:194-203.

Blemings, K. P., T. D. Crenshaw, and N. J. Benevenga. 1998. Mitochondrial lysine uptake limits hepatic lysine oxidation in rats fed diets containing 5, 20, or $60 \%$ casein. J. Nutr. 128:2427-2434.

Blemings, K. P., T. D. Crenshaw, R. Swick, and N. J. Benevenga. 1990. Response of rat hepatic mitochondria lysine oxidation (Lys $\mathrm{Ox})$, lysine $\alpha$-ketoglutarate reductase $(\mathrm{L} \alpha-\mathrm{KGR})$ and saccharopine dehydrogenase $(\mathrm{SacD})$ to 5,18 , and $60 \%$ casein diets. FASEB J. 4:A919.

Brenaut, P., R. Bangera, C. Bevilacqua, E. Rebours, C. Cebo, and P. Martin. 2012. Validation of RNA isolated from milk fat globules to profile mammary epithelial cell expression during lactation and transcriptional response to a bacterial infection. J. Dairy Sci. 95:6130-6144.

Burrin, D. G., T. A. Davis, S. Ebner, P. A. Schoknecht, M. L. Fiorotto, P. J. Reeds, and S. McAvoy. 1995. Nutrient-independent and nutrient-dependent factors stimulate protein synthesis in colostrumfed newborn pigs. Pediatr. Res. 37:593-599.

Cánovas, A., G. Rincón, C. Bevilacqua, A. Islas-Trejo, P. Brenaut, R. C. Hovey, M. Boutinaud, C. Morgenthaler, M. K. VanKlompenberg, P. Martin, and J. F. Medrano. 2014. Comparison of five different RNA sources to examine the lactating bovine mammary gland transcriptome using RNA-sequencing. Sci. Rep. 4:5297-5303.

Cant, J. P., R. Berthiaume, H. Lapierre, P. H. Luimes, B. W. McBride, and D. Pacheco. 2002. Responses of the bovine mammary glands to absorptive supply of single amino acids. Can. J. Anim. Sci. 83:341-355.

Chu, S. H., and D. M. Hegsted. 1976. Adaptive response of lysine and threonine degrading enzymes in adult rats. J. Nutr. 106:1089-1096.

Cleveland, B. M., A. S. Kiess, and K. P. Blemings. 2008. $\alpha$-Aminoadipate $\delta$-semialdehyde synthase mRNA knockdown reduces lysine requirement of a mouse hepatic cell line. J. Nutr. 138:2143-2147.

Davis, T. A., H. V. Nguyen, R. Garcia-Bravo, M. L. Fiorotto, E. M. Jackson, and P. J. Reeds. 1994. Amino acid composition of the milk of some mammalian species changes with stage of lactation. Br. J. Nutr. 72:845-853.

Foster, A. R., P. W. D. Scislowski, C. I. Harris, and M. F. Fuller. 1993. Metabolic response of liver lysine $\alpha$-ketoglutarate reductase activity in rats fed lysine limiting or lysine excessive diets. Nutr. Res. 13:1433-1443

Gatrell, S. K., L. E. Berg, J. T. Barnard, J. G. Grimmett, K. M. Barnes, and K. P. Blemings. 2013. Tissue distribution of indices of lysine catabolism in growing swine. J. Anim. Sci. 91:238-247.

Goering, H. K., and P. J. VanSoest. 1970. Forage Fiber Analyses (Apparatus, Reagents, Procedures, and Some Applications). Agric. Handbook No. 379. ARS-USDA, Washington, DC.

Greenfield, R. B., M. J. Cecava, T. R. Johnson, and S. S. Donkin. 2000. Impact of dietary protein amount and rumen undegradability on intake, peripartum liver triglyceride, plasma metabolites, and milk production in transition dairy cattle. J. Dairy Sci. 83:703-710.

Gressley, T. F., S. M. Reynal, J. J. Olmos Colmenero, G. A. Broderick, and L. E. Armentano. 2006. Technical note: Development of a tool to insert abomasal infusion lines into dairy cows. J. Dairy Sci. 89:3965-3967.

Guinard, J., and H. Rulquin. 1994. Effects of graded amounts of duodenal infusions of lysine on the mammary uptake of major milk precursors in dairy cows. J. Dairy Sci. 77:3565-3576.

Hanigan, M. D., J. P. Cant, D. C. Weakley, and J. L. Beckett. 1998. An evaluation of postabsorptive protein and amino acid metabolism in lactating dairy cow. J. Dairy Sci. 81:3385-3401.

Hanigan, M. D., L. A. Crompton, C. K. Reynolds, D. Wray-Cahen, M. A. Lomax, and J. France. 2004. An integrative model of amino acid metabolism in the liver of lactating dairy cow. J. Theor. Biol. 228:271-289.

King, K. J., W. G. Bergen, C. J. Sniffen, A. L. Grant, D. B. Grieve, V. L. King, and N. K. Ames. 1991. An assessment of absorbable lysine requirements in lactating dairy cows. J. Dairy Sci. 74:2530-2539.

Lapierre, H., R. Berthiaume, G. Raggio, M. C. Thivierge, L. Doepel, D. Pacheco, P. Dubreuil, and G. E. Lobley. 2005. The route of absorbed nitrogen into milk protein. Anim. Sci. 80:11-22. 
Lapierre, H., L. Doepel, E. Milne, and G. E. Lobley. 2009. Responses in mammary and splanchnic metabolism to altered lysine supply in dairy cows. Animal 3:360-371.

Lapierre, H., and G. E. Lobley. 2001. Nitrogen recycling in the ruminant: A review. J. Dairy Sci. 84:E223-E236.

Lapierre, H., E. Milne, J. Renaud, and G. E. Lobley. 2003. Lysine utilization by the mammary gland. Pages $777-780$ in Progress in Research on Energy and Protein Metabolism. No. 109. W. B. Souffrant and C. C. Metges, ed. EAAP Scientific Series. Wageningen Academic Publishers, Wageningen, the Netherlands.

Lapierre, H.,, G. E. Lobley, L. Doepel, G. Raggio, H. Rulquin, and S. Lemosquet. 2012. Mammary metabolism of amino acids in dairy cows. J. Anim. Sci. 90:1708-1721.

Lobley, G. E., and H. Lapierre. 2003. Post-absorptive metabolism of amino acids. Pages 737-756 in Progress in Research on Energy and Protein Metabolism. No. 109. W. B. Souffrant and C. C. Metges, ed. EAAP Scientific Series. Wageningen Academic Publishers, Wageningen, the Netherlands.

Marino, R., M. Iammarino, A. Santillo, M. Muscarella, M. Caroprese, and M. Albenzio. 2010. Rapid method for determination of amino acids in milk. J. Dairy Sci. 93:2367-2370.

Markovitz, P. J., and D. T. Chuang. 1987. The bifunctional aminoadipic semialdehyde synthase in lysine degradation: Separation of reductase and dehydrogenase domains by limited proteolysis and column chromatography. J. Biol. Chem. 262:9353-9358.

Markovitz, P. J., D. T. Chuang, and R. P. Cox. 1984. Familial hyperlysinemias: Purification and characterization of the bifunctional aminoadipic semialdehyde synthase with lysine-ketoglutarate reductase and saccharopine dehydrogenase activities. J. Biol. Chem. 259:11643-11646.

Muramatsu, K., R. Takada, and K. Uwa. 1984. Adaptive responses of liver and kidney lysine-ketoglutarate reductase and lysine oxidation in rats fed graded levels of dietary lysine and casein. Agric. Biol. Chem. 48:703-711.
NRC. 2001. Nutrient Requirements of Dairy Cattle. 7th rev. ed. Natl. Acad. Sci., Washington, DC.

Papes, F., E. L. Kemper, G. Cord-Neto, F. Langone, and P. Arruda. 1999. Lysine degradation through the saccharopine pathway in mammals: Involvement of both bifunctional and monofunctional lysine-degrading enzymes in mouse. Biochem. J. 344:555-563.

Pink, D. B. S., S. K. Gatrell, R. Elango, J. Turchinsky, A. S. Kiess, K. P. Blemings, W. T. Dixon, and R. O. Ball. 2011. Lysine $\alpha$-ketoglutarate reductase, but not saccharopine dehydrogenase, is subject to substrate inhibition in pig liver. Nutr. Res. 31:544-554.

Robinson, P. H. 2010. Impacts of manipulating ration metabolizable lysine and methionine levels on the performance of lactating dairy cows: A systematic review of the literature. Livest. Sci. 127:115126.

Rulquin, H., P. M. Pisulewski, R. Vérite, and J. Guinard. 1993. Milk production and composition as a function of postruminal lysine and methionine supply: A nutrient-response approach. Livest. Prod. Sci. 37:69-90.

Schwab, C. G., and R. S. Ordway. 2004. Balancing diets for amino acids: Implications on production efficiency and feed costs. Pages 1-16 in Penn. State Dairy Cattle Nutr. Wkshp., Grantville, PA. The Pennsylvania State University, University Park.

Snodgrass, P. J., and R. C. Lin. 1981. Induction of urea cycle enzymes of rat liver by amino acids. J. Nutr. 111:586-601.

Van Soest, P. J., J. B. Robertson, and B. A. Lewis. 1991. Methods for dietary fiber, neutral detergent fiber, and nonstarch polysaccharides in relation to animal nutrition. J. Dairy Sci. 74:3583-3597.

Varvikko, T., A. Vanhatalo, T. Jalava, and P. Huhtanen. 1999. Lactation and metabolic responses to graded abomasal doses of methionine and lysine in cows fed grass silage diets. J. Dairy Sci. 82:2659-2673 